\section{Race: talented minorities face a 'revolving door'}

SIR - Your News story 'Researcher refuses to back down over race case' (Nature 447, $762-763$; 2007) calls attention to the courageous stand taken by James Sherley, an assistant professor at Massachusetts Institute of Technology (MIT) who believes that he was denied tenure because of racial discrimination.

Remarkably, although there has long been a high percentage of African-American students at leading US universities - 10\% of incoming undergraduates at MIT, for example - very few have so far made it through to tenure. Only about $1 \%$ of biology professors at US universities are AfricanAmericans. Although one-third of assistant professors overall may make it to tenure at MIT, hardly any African-American assistant professors have ever done so in MIT's core disciplines of science and engineering. The same seems to be true at most leading US universities, leading to what has been termed a 'revolving door' for even very talented young African-American scientists such as Sherley, who last year won a National Institutes of Health Pioneer award for innovative work.

How can it be that white and black scientists who initially seem equally talented have such different chances of making it to tenure? I would argue that it is because present tenure policies are unintentionally designed to prevent the success of even the most talented minority scientists.

At places like MIT, only a fraction of faculty make it, even if they're white. In the face of pervasive racial barriers, how can talented minorities have a fair chance in such a steeply competitive timed-tenure system? These barriers can include lack of equal space and resources, lack of mentoring by senior faculty, lack of inclusion in faculty activities such as invitations to speak in seminar series, a general lack of recognition and support, and a hesitancy among white students to join the labs of minority faculty or to be referred to minority labs by senior faculty.

In the face of so many obstacles, how is it fair to argue that Sherley does not deserve tenure because he didn't publish quite as many papers as white assistant professors who did not face any of these barriers? Although the MIT faculty and administrators who have considered his tenure application are for the most part well-meaning, they seem to be unaware of the reality of persisting racial barriers. They unfairly prefer to attribute lack of success to inability.

In a survey of MIT students in 1985, it was found that African-Americans have surprisingly few meaningful faculty contacts, most of those being with the tiny percentage of the faculty who are ethnic minorities. If minority students and faculty are to be successful, there is an urgent need for universities to re-evaluate and redesign their policies that control retention of ethnic minorities on their faculty.

\section{Ben Barres}

Department of Neurobiology,

Stanford University School of Medicine,

Fairchild Room D235, 299 Campus Drive,

Stanford, California 94305-5125, USA

\section{Race and tenure case was not handled fairly by MIT}

SIR - Although tenure evaluations are not primarily accountings of publications, you reported in your News story 'Researcher refuses to back down over race case' (Nature 447, 762-763; 2007) that I published six peer-reviewed research papers during the years before the decision taken by Massachusetts Institute of Technology (MIT) about my tenure.

My years as a principal investigator before MIT's decision include research at the Fox Chase Cancer Center in Philadelphia. MIT's tenure decision should have been based on my comprehensive work as a principal investigator, not limited only to time at MIT. The MIT faculty personnel record submitted for my tenure evaluation listed 41 scholarly articles published, in press, or accepted for publication, including 11 peer-reviewed primary-research articles, two peer-reviewed review articles, five peer-reviewed proceedings papers and four book chapters (two peer-reviewed). Not included in this total are four research manuscripts submitted to peer-reviewed journals and 10 published patent applications.

Your comparison of my tenure application with those of two other faculty awarded tenure at the same time is not a fair comparison, because people who arrive at an institution mid-career are not comparable to those who began their faculty careers at the institution at which they later apply for tenure. Their research programmes are at a different stage of maturity, and often the projects undertaken differ significantly in degree of challenge and impact. Even so, another mid-career faculty member received MIT tenure within the same timeframe as my application, largely on the basis of contributions that had been made before arrival there.

My main complaint against MIT is the manner in which my case was decided by the faculty chair. For example, at MIT, when a tenure-case decision is being made, review of the case is prohibited outside its department. If the case is not advanced to the next level of review, it is sealed. So why was a professor who is neither a member of my faculty nor an expert in my field - stem-cell biology - asked by the faculty chair to review the case before the decision was announced? James Sherley

Department of Biological Engineering,

Biotechnology Process Engineering Center,

Center for Environmental Health Sciences,

Center for Cancer Research,

MIT, Cambridge, Massachusetts 02139, USA

\section{Foundation active in fight to cure Huntington's}

SIR - Your News Feature on biomedical philanthropy 'Love or money' (Nature 447, 252-253; 2007) states that that the High Q Foundation is a successor to the Hereditary Disease Foundation (www.hdfoundation. org). You also state that CHDI is a successor to the Cure Huntington's Disease Initiative of the Hereditary Disease Foundation. The word 'successor' could give readers the false impression that the Hereditary Disease Foundation either no longer exists or is no longer active. This is incorrect. The Hereditary Disease Foundation, since its inception in 1968, has vigorously encouraged and respectfully supported researchers seeking to find treatments and cures for Huntington's disease as rapidly as possible and continues to do so.

Nancy Wexler ${ }^{\star} \uparrow$, Carl Johnson $\uparrow$

*Departments of Neurology and Psychiatry, Columbia University, 1051 Riverside Drive, Unit 6, PI Annex 371, New York, New York 10032, USA tHereditary Disease Foundation, 3960 Broadway, 6th Floor, New York, New York 10032, USA

\section{Friendly clarification from City of Brotherly Love}

SIR - I thoroughly enjoy Nature's insightful columns and News and Views, and of course take a special satisfaction when researchers from my institution, the University of Pennsylvania (or U Penn) are featured. However, in a sidebar 'Body and mind' within the News Feature 'Brain craze' (Nature 447, 18-20; 2007), a researcher is reported to work at Pennsylvania State University (Penn State) in Philadelphia. There have been occasional other instances in your pages of confusion over Pennsylvania and its universities.

Neither Penn State nor the University of Pittsburgh (Pitt) is in Philadelphia, the state's largest city, located in its southeastern corner. $\mathrm{U}$ Penn is a private university in the city, founded by its most famous citizen, Benjamin Franklin.

Penn State is the state's (and maybe the country's) largest public university, and it has many campuses, the main one located in University Park, Pennsylvania. The legend is that the location of the university was chosen 